\title{
Study on the Formula of Moringa Noodles
}

\author{
Suhui Zhang ${ }^{1,2}$, Wei Zhou ${ }^{1}$, Liangkun Liao ${ }^{1}$, Jihua Li ${ }^{1,}$ a, ${ }^{*}$, Lijing Lin ${ }^{1}$, \\ Changqing $\mathrm{Guo}^{3}$ \\ ${ }^{1}$ Key Laboratory of Tropical Crop Products Processing of Ministry of Agriculture, Agricultural \\ Products Processing Research Institute, Chinese Academy of Tropical Agricultural Sciences, \\ Zhanjiang, 524001, China \\ ${ }^{2}$ College of Food Science and Technology of Huazhong Agricultural University, No. 1, Shizishan \\ Road, Hongshan District, Wuhan, Hubei Province, 430070, China \\ ${ }^{3}$ Henan Gold Moringa Biotechnology Co., Ltd., Hebi, Henan, 458000, China \\ afoodpaper@126.com
}

Keywords: Moringa; noodles; orthogonal experiment; sensory evaluation.

\begin{abstract}
In order to improve the nutritional value of the noodles products, we added some ingredients in noodles and Moringa noodles were made. In this paper, the wheat flour was used as the raw material, adding appropriate amount of Moringa powder, and study on the formula of Moringa noodles. The experiment took the optimization of the orthogonal experimental design and analysis. The optimum conditions for wheat flour: distilled water: Moringa powder were mixed with the ratio of 200:90:10. According to the optimal scheme for the sensory evaluation of Moringa noodles was Grain powder $2.5 \%$, CNC $0.3 \%$, edible alkali $0.2 \%$, salt $2.0 \%$, and the noodles display good quality and the sensory score was 81 .
\end{abstract}

\section{Introduction}

Moringa oleifera, also known as drumstick tree, white cauliflower, is a species belonging to the Moringaceae family. Originating in India and its name owing to roots with spicy. The whole plant has edible value, roots and bark is traditional medicine raw materials, oil is rich in its seeds and can be used as a storage of edible vegetable oil. Moringa leaves are vegetables which it has a large amount of nutrition, such as protein, minerals, vitamins and calcium, potassium, iron and other mineral elements, is a comprehensive nutritional supplement. Moringa have the effect of improving immunity, anti-inflammatory, analgesic, preventing and treating diabetes, hypertension and other effects, therefore Moringa is widely applied in medical and health care, etc ${ }^{[1-6]}$. It was reported that Moringa is recognized for its nutritional properties. Moringa leaves can be fresh to eat, eat cooked or made into powder storage, it can even preserve a few months without the loss of nutrients at room temperature. It is reported that daily consumption of $25 \mathrm{~g}$ Moringa leaves dry powder, the body can get the $42 \%$ protein, $125 \%$ calcium, $61 \%$ magnesium, $41 \%$ potassium, $71 \%$ iron, $272 \%$ vitamin A and others of the recommended standard.

At present in Chinese, the nutritional value of Moringa has been recognized by people, but there still exist some limits in the development of products. The visible products in market is mostly the substitute tea with other compounds of Moringa leaves, the use of nutritional food additives just have Moringa flour products. The research of its active ingredient and the product development has become a hot spot. So the depth development and utilization of Moringa has important economic value and social significance [7-9].

\section{Materials and Methods}

\subsection{Material}

Moringa powder, Plain flour purchased from the market. 


\subsection{Process Flow}

First take the appropriate amount of raw material (the salt dissolved in water in advance), then stir them to make it mixed evenly, next knead the dough to place the dough fluffy, and forming by pressing. Final cut into strips to dry naturally and can put into the bag to wait be tested.

\subsection{Determine the Basic Formula of the Product}

Based on the exploratory experiment pre-period, decided to select 4 important factors for this experiment: grain powder, CNC, dietary alkali and salt respectively. And design the experiment of four factors and three levels orthogonal test [10]. The sensory score was taken as the investigation index in order to determine the best product formula. Factors and levels were shown in Table 1.

Table 1 Factors and levels of the orthogonal experiment

\begin{tabular}{ccccc}
\hline level & $\begin{array}{c}\text { Grain powder } \\
(\mathrm{A}) / \%\end{array}$ & $\begin{array}{c}\text { CNC } \\
(\mathrm{B}) / \%\end{array}$ & $\begin{array}{c}\text { Dietary alkali } \\
(\mathrm{C}) / \%\end{array}$ & $\begin{array}{c}\text { Salt } \\
\text { (D) } / \%\end{array}$ \\
\hline 1 & 2.0 & 0.25 & 0.15 & 1.5 \\
2 & 2.5 & 0.30 & 0.20 & 2.0 \\
3 & 3.0 & 0.35 & 0.25 & 2.5 \\
\hline
\end{tabular}

\subsection{Sensory Evaluation Methods}

The comment group was composed of 10 students, and mainly focused on the color, appearance, palatability, toughness, viscosity, smoothness and taste evaluation. In order to improve the credibility of the evaluation, for the member of the comment group should not drink alcohol, not smoking and not eat spicy food before tasting. And after evaluating a sample, remember to gargle with water and then evaluate the next sample and develop the evaluation criteria. (Table 2)

Table 2 Sensory evaluation standard of Moringa noodles

\begin{tabular}{|c|c|c|c|}
\hline $\begin{array}{l}\text { Sensory } \\
\text { index }\end{array}$ & \multicolumn{3}{|c|}{ Grading standard } \\
\hline $\begin{array}{l}\text { The index of } \\
\text { Color } \\
10 \text { score }\end{array}$ & $\begin{array}{c}\text { Refers to the color and brightness } \\
\text { of noodles, noodles with natural } \\
\text { pale red or dark red, bright } \\
8.5 \sim 10 \text { score }\end{array}$ & $\begin{array}{l}\text { The brightness is } \\
\text { commonly } \\
6 \sim 8.4 \text { score }\end{array}$ & $\begin{array}{l}\text { Brown, gray, the score } \\
\text { of brightness is } \\
1 \sim 6 \text { score }\end{array}$ \\
\hline $\begin{array}{l}\text { Apparent } \\
\text { state } \\
10 \text { score }\end{array}$ & $\begin{array}{l}\text { Refers to the surface is smooth } \\
\qquad 8.5 \sim 10 \text { score }\end{array}$ & $\begin{array}{l}\text { The surface of the noodles } \\
\text { is slightly rough } \\
6.0 \sim 8.4 \text { score }\end{array}$ & $\begin{array}{c}\text { The surface of the } \\
\text { noodles is terrible } \\
1 \sim 6 \text { score }\end{array}$ \\
\hline $\begin{array}{l}\text { Palatability } \\
20 \text { score }\end{array}$ & $\begin{array}{l}\text { The power of biting the noodles } \\
\text { is moderate } \\
17 \sim 20 \text { score }\end{array}$ & $\begin{array}{c}\text { The power of biting the } \\
\text { noodles is stiff or soft } \\
\text { slightly } \\
12 \sim 17 \text { score }\end{array}$ & $\begin{array}{c}\text { The strength of biting } \\
\text { the noodles is too hard } \\
\text { or too soft } \\
1 \sim 12 \text { score }\end{array}$ \\
\hline $\begin{array}{l}\text { Toughness } \\
25 \text { score }\end{array}$ & $\begin{array}{l}\text { When the noodles are chewing, } \\
\text { the feel of chewing is full of } \\
\text { elasticity } \\
21 \sim 25 \text { score }\end{array}$ & $\begin{array}{l}\text { Chewing generally and } \\
\text { elastic in general } \\
15 \sim 21 \text { score }\end{array}$ & $\begin{array}{l}\text { Lack of flexibility } \\
1 \sim 15 \text { score }\end{array}$ \\
\hline $\begin{array}{l}\text { Viscosity } \\
25 \text { score }\end{array}$ & $\begin{array}{l}\text { In the chewing process, the } \\
\text { noodles are not sticky teeth } \\
21 \sim 25 \text { score }\end{array}$ & $\begin{array}{l}\text { When chewing the } \\
\text { noodles, the feel is slightly } \\
\text { sticky teeth } 15 \sim 21 \text { score }\end{array}$ & $\begin{array}{c}\text { In the process of } \\
\text { chewing noodles, } \\
\text { sticky teeth seriously } \\
1 \sim 15 \text { score } \\
\end{array}$ \\
\hline $\begin{array}{l}\text { Smoothness } \\
5 \text { score }\end{array}$ & $\begin{array}{l}\text { The taste is smooth when tasting } \\
\text { the noodles } \\
4.3 \sim 5 \text { score }\end{array}$ & $\begin{array}{l}\text { The taste of noodles is } \\
\text { slightly rough } \\
3 \sim 4.3 \text { score }\end{array}$ & $\begin{array}{l}\text { Poor smoothness } \\
1 \sim 3 \text { score }\end{array}$ \\
\hline $\begin{array}{l}\text { Taste } \\
5 \text { score }\end{array}$ & $\begin{array}{l}\text { The taste of noodles are fragrant } \\
4.3 \sim 5 \text { score }\end{array}$ & $\begin{array}{l}\text { No unpleasant taste } 3 \sim 4.3 \\
\text { score }\end{array}$ & $\begin{array}{c}\text { There is an unpleasant } \\
\text { taste } \\
1 \sim 3 \text { score }\end{array}$ \\
\hline
\end{tabular}

\subsection{The Determination of The Texture of Noodles}

Weighing $50 \mathrm{~g}$ noodles sample, and put it in a small aluminum pot with $500 \mathrm{ml}$ boiling water which heating on a $200 \mathrm{~W}$ electric furnace, when the white core disappeared, and gain noodles 
immediately then add cold water cooling for $2 \mathrm{~min}$ and taking 3 root noodles put on texture instrument, then determine the texture of noodles. The average value was measured by 5 groups of data. All speed of pre-measured, determination speed and after the determination speed are $0.8 \mathrm{~m} / \mathrm{s}$. The deformation rate is $75 \%$; the type of trigger is automatic and the power of trigger is $5.0 \mathrm{~g}$. The type of probe is TA3/100 and cycle number is 2 times.

\section{Results and Discussion}

\subsection{Determine the Basic Formula of the Product}

This is a test of 4 factors and 3 levels which the indicators to be investigated is the comprehensive score of sensory evaluation. The higher the score, the better the effect. Since the interaction was not considered, the orthogonal table L9 $\left(3^{4}\right)$ can be used to arrange the test and can get the results of orthogonal experiment. (Table 3)

Table 3 The results of orthogonal test

\begin{tabular}{|c|c|c|c|c|c|}
\hline \multirow{2}{*}{ Number } & \multicolumn{4}{|c|}{ Factor } & \multirow{2}{*}{ score } \\
\hline & A & $\mathrm{B}$ & $\mathrm{C}$ & $\mathrm{D}$ & \\
\hline 1 & 1 & 1 & 1 & 1 & 74.40 \\
\hline 2 & 1 & 2 & 2 & 2 & 75.50 \\
\hline 3 & 1 & 3 & 3 & 3 & 74.60 \\
\hline 4 & 2 & 1 & 2 & 3 & 76.30 \\
\hline 5 & 2 & 2 & 3 & 1 & 77.10 \\
\hline 6 & 2 & 3 & 1 & 2 & 77.80 \\
\hline 7 & 3 & 1 & 3 & 2 & 74.70 \\
\hline 8 & 3 & 2 & 1 & 3 & 76.40 \\
\hline 9 & 3 & 3 & 2 & 1 & 76.10 \\
\hline $\mathrm{K} 1$ & 224.50 & 225.40 & 228.60 & 227.60 & \\
\hline K2 & 231.00 & 229.00 & 227.90 & 228.00 & \\
\hline K3 & 227.40 & 228.50 & 226.40 & 227.30 & \\
\hline k1 & 74.83 & 75.13 & 76.20 & 75.87 & \\
\hline k2 & 77.00 & 76.33 & 75.97 & 76.00 & \\
\hline k3 & 75.80 & 76.17 & 75.47 & 75.77 & \\
\hline $\mathrm{R}$ & 2.17 & 1.20 & 0.73 & 0.23 & \\
\hline Main factors sort & & & A B C D & & \\
\hline Optimal scheme & & & $\mathrm{A}_{2} \mathrm{~B}_{2} \mathrm{C}_{1} \mathrm{D}_{2}$ & & \\
\hline
\end{tabular}

From the table, we can get the result of maximum polarity was $\mathrm{A}$, then $\mathrm{B}$ was second, the rank of $\mathrm{C}$ was third, and $\mathrm{D}$ was minimum. That was to say, the amount of grain powder had the greatest impact on Moringa noodles quality, and the amount of CNC was less. The amount of edible alkali had the minimum influence on the quality of Moringa noodles. According to the range analysis, the optimum process parameters were $\mathrm{A}_{2} \mathrm{~B}_{2} \mathrm{C}_{1} \mathrm{D}_{2}$, so the amount of grain powder, $\mathrm{CNC}$, edible alkali, and salt were $2.50 \%, 0.30 \%, 0.15 \%$, and $2 \%$ respectively, then could get the best quality of Moringa noodles which the sensory indicators such as taste, toughness, texture, viscosity and et al can get the standard of excellent. 


\subsection{The Determination of the Texture}

Table 4 The comparison of the texture between Moringa noodles on the market and the products from the experiment

\begin{tabular}{cccccc}
\hline & hardness & viscosity & elasticity & gumminess & chewiness \\
Market products & $15.22 \pm$ & $1.54 \pm$ & $1.23 \pm$ & $7.37 \pm$ & $8.94 \pm$ \\
& 4.94 & 1.23 & 0.18 & 1.33 & 1.11 \\
Experiment products & $20.22 \pm$ & $1.86 \pm$ & $1.51 \pm$ & $6.10 \pm$ & $9.4 \pm$ \\
& 2.98 & 0.37 & 0.35 & 0.95 & 3.48 \\
\hline
\end{tabular}

Through the table we could get clearly the index of the hardness, the viscosity, the elasticity and the chewiness were higher than the market, the gumminess was lower than the market, and had a better taste, it was easier to chew and did not stick to the teeth, even the repeatability of the data was better than the market.

Finally, according to the SB/T-10068 to be compared, the ratio of the measured by the index of Moringa noodles were within the range of product level, belongs to first grade product.

\section{Conclusion}

At present, the research about Moringa is more focused on the cultivation technology, but the development of products about Moringa in the field of food is less. Because of the nutritional value of Moringa noodles is higher, has broad prospects for the development. According to the optimum conditions for wheat flour: distilled water: Moringa powder were mixed with the ratio of 200:90:10. And the optimal scheme for the sensory evaluation of Moringa noodles is: Grain powder 2.5\%, CNC $0.3 \%$, edible alkali $0.2 \%$, salt $2.0 \%$, the noodles display good quality. The ratio of the measured by the index of Moringa noodles were within the range of product level, belongs to first grade product. With the deeper study about Moringa, we can believe Moringa noodles will occupy a larger share in the market in the near future, and will have better prospects for the development.

\section{Acknowledgements}

This research was supported by Central Public-interest Scientific Institution Basal Research Fund for Chinese Academy of Tropical Agricultural Sciences (No. 1630122016007), Central Publicinterest Scientific Institution Basal Research Fund for Chinese Academy of Tropical Agricultural Sciences (No. 1630122016011) and the Project of Guangxi Science Research and Technology Development (Project No. 15248003-18).

\section{References}

[1]. Zhang Yanping, Duan Qiongfen,Su Jianrong. The development and utilization of Moringa, J. Tropical Agricultural Science. 24(4), 42-48 (2004).

[2]. Pan Lijun, Liu Xiaojin. Research Progress on Cultivation and utilization of Moringa, J. Guangdong forestry science and technology. 26(3), 71-77 (2010).

[3]. Zhong Huihui, Ma Haile, Zhang tao, et al. Present situation and Prospect of development and utilization of Moringa oleifera, J. Grain and oil food science and technology. 14 (2), 60-61 (2006).

[4]. Liu Changfen, Li Guohua. The research status and development prospect of Moringa oleifera, J. Yunnan thermal technology. 25(3), 20-24 (2002).

[5]. Muthuvelayudham R, Viruthagiri T. Application of central composite design based response surface methodology in parameter optimization and on cellulase production using agricultural waste, J. International Journal of Chemical and Biological Engineering. 3(2), 97-104 (2010).

[6]. Rao Zhikun, Feng Liangyan, Licong, et al. Analysis and research of the nutritional composition of Moringa oleifera, J. Modern instrument. (2), 18-20 (2007).

[7]. Zhang Li, Zhang Cheng, She Lina.A review on the development of Moringa industry, J. Yunnan Forestry. (5), 66-67 (2014). 
[8]. Liu Ziji, Sun Jihua, Liu zhaohua, et al. Analysis on the application value and development prospects of Moringa plant characteristics, J. Journal of Tropical Crops. (9), 215-222 (2014).

[9]. Zheng Yi, Xie Peihui, Wubin, et al. Experimental study on afforestation of Moringa Jinsha river dry hot valley, J. China's rural well-off science and technology. (2), 52-54 (2011).

[10]. Liu Ruijiang, Zhang Yewang, Wen Chongwei, et al. Orthogonal experimental design and analysis method research, J. Experimental technology and management. 09, $52-55$ (2010). 